Linguistik Terapan 15 (3) (2018): 237-244

Jurnal Linguistik Terapan Pascasarjana

Available online

http://jurnal.unimed.ac.id/2018/index.php/JLT-Unimed

\title{
EUPHEMISM OF SURAH AL-BAQARAH IN THE HOLY QUR'AN
}

\author{
Nurhalimah Tamba \\ Anni Holila Pulungan \\ Amrin Saragih \\ English Applied Linguistics Program \\ Postgraduate Program - Universitas Negeri Medan
}

Diterima September 2018; Disetujui Oktober 2018; Dipublikasikan Desember 2018

ABSTRACT

This study deals with euphemism of surah Al-Baqarah in the Holy Qur'an. It was aimed to describe realization of euphemistic expressions in surah Al-Baqarah. This study was conducted by using descriptive qualitative research. The data analyzed were verses of surah Al-Baqarah which contained euphemism. The source of the data was taken from Tafseer Ibn Kathir Vol 1-10 in the English language with Arabic verses. The researcher is the key instrument of the research. The findings show that there are four the ways of euphemism realized in surah Al-Baqarah, namely direct, indirect, implicit, and explicit. The dominant of ways realized euphemism in surah Al-Baqarah was direct. It means that the most of euphemism to describe truth from Allah is real and Allah delivered messangers directly about the laws of Allah so that they can know the truth.

Keyword: Euphemism, Taboo, Surah Al-Baqarah

How to Cite: Tamba, Nurhalimah(2018)

Euphemism of Surah Al-Baqarah in the Holy Qur'an. Jurnal Linguistik Terapan Pascasarjana Unimed, 15 (3): 237

*Corresponding author:

ISSN 0216-5139

E-mail:tambanurhalimah@yahoo.com 


\section{INTRODUCTION}

language expresses the feeling and attitude of the speaker and writer. In conversation, people tend to use language with many variations in order to deliver what they want. In daily life, when someone speaks to other their usually use feeling to avoid of using bad words whenever it is something taboo to say it (Wardaugh, 2006).

In the life of human as a creature of God cultured to note how one expresses the words in either language (euphemism), especially regarding the use of words that are culturally significant to be expressed in the language. There are some words that should be avoided, both for spoken and expressed because it is seen as taboo and forbidden to publish. To avoid the use of a language that is taboo, there is a study of language called euphemism.

Rawson (1995) explains that euphemism is a word (a phrase) which people use in place of terms which more disagreeable or offensive to themselves to their audience. When a phrase becomes a euphemism, its literal meaning is often pushed a side. Euphemism is used to hide unpleasant ideas, when the term for them is not necessary offensive.

Furthermore, Allan and Burridge (1991) stated that euphemism is alternatives to dispreferred expressions, and are used to avoid possible loss of face. The dispreferred expression may be taboo, fearsome, distasteful, or for some other reason has too many negative connotations to felicitously execute speaker's communicative intention on a given occasion. Euphemism seems to be culturally sensitive areas in many languages and cultures, religion, death, disease, sex, parts of body and bodily function. They also add that euphemisms have survived throughout history and they are used even among the primitive people.

Euphemism is a useful tool that allows language users to write or speak figuratively about the libelous issues, i.e. it is a linguistic device to avoid talking about unpleasant realities directly.English has a lot of euphemistic terms and expressions such as: pass away instead of die, put to sleep instead of kill, pillow biter as alternative for homosexual and restroom as compensation from toilet or lavatory (Hudson, 2000).

The use of euphemistic language reveals much about the relationship between the speaker and the addressee or some third party. This is true mainly because the speaker's option for euphemism is absolutely deliberate. For instance, a speaker may intentionally resort to using emotive euphemistic expressions in order to highlight the intended meaning to be conveyed through language, since euphemism is generally associated with positive emotiveness. Thus, speakers use euphemisms so as to get rid of taboo words, to create social politeness, to protect people from misfortune, and not to hurt or offend listeners or other 
speakers (Warren, 1992). Euphemism is not only a common strategy in people's daily communication which can make a harsh topic softer and an embarrassed conversation agreeable but also euphemism used in Holy Qur'an.

In daily life, many Muslims misinterpretated the meaning of ayah in the holy Qur'an especially taboo. In addition, many problems addressed in the Glorious Qur'an are misinterpreted. It misinterpretation is due to decontextualizing a euphemistic expression linguistically and culturally, and failure to regard the Qur'anic style properly. And the reader only know translate of holy Qur'an without understanding the content and meaning in it.

Surah Al-baqarah is the longest surah in the Glorious Qur'an which carries teachings to Muslims in sensitive topics which necessitate the use of euphemisms. In addition, surah Al-baqarah not only discusses about marital relation but also addresses a wide variety of topics, including substantial amounts of law, and retells stories of Adam, Abraham and Moses, a few Islamic rules related to varying subjects, such as: prayers, fasting, striving on the path of God, the pilgrimage to Mecca, the change of the direction of prayer (Qiblah) from Jerusalem to Mecca, marriage and divorce, commerce, debt, and a great many of the ordinances concerning usury.

Many of the previous research which studies about euphemism as the study was conducted in 2013 by Hamad and Salman. This study investigated of the translation of euphemistic expressions in the Holy Quran. The result showed that euphemism is an evident phenomenon in the Holy Quran and that the process of translating it into English is generally problematic for reasons such as linguistic and cultural diversity.

Furthermore, Rodulovic (2012), the study analyzed the ways are expressed in positive and negative Euphemisms. The results of this analysis used to explain the pragmatic mechanisms that can help relate the meaning of Inoffensive terms to their more direct counterparts.

Those previous studies above show the ways realization of euphemistic expression have different perspective. Therefore, based on the phenomena mention above, this study investigated the euphemism of surah Al-Baqarah in the holy Qur'an to describe realization of euphemistic expressions in surah Al-Baqarah.

\section{RESEARCH METHOD}

This research was conducted by applying descriptive qualitative design to explain euphemism of surah Al-Baqarah in Holy Qur'an. Bogdan and Biklen (1992) described that qualitative was descriptive, where data is in the form of words or pictures rather than numbers. In this study, the data were verses of surah Al-Baqarah consisted of 286 verses and 
source of the data were taken from Tafseer Ibn Kathir Vol 1-10 in the English language with Arabic verses.

The data was collected by applying a documentary technique. According to Burhan (2007), documentary technique is a method for collecting the data which is kept in the form of textbook, report of the research, newspaper, magazine, journal, internet sites, TV, radio which considered relevant with the research.This study, Alqur'anhas been read and then verses of surah Al-Baqarah were selected to describerealization euphemistic expression and the last elaborating the finding which have analyzed.

The data in this study wereanalyzed by using interactive technique Miles, Hubermanand Saldana's theory. According to Miles, Huberman and Saldana (2014), the phases of data analysis are divided into three parts, there are data condensation, data display, conclusion drawing and verification.

\section{FINDINGS AND DISCUSSIONS}

Based on the data analysis of the study, it is found that there are four ways euphemism realization in surah Al-Baqarah, namely implicit, explicit, direct, and indirect.

a. Implicit

Theoretically, implicit refers to impliedthoughnotdirectlyexpressed;inherent in thenature of something. There were some verses of euphemism realized implicitly. The data can be seen below:

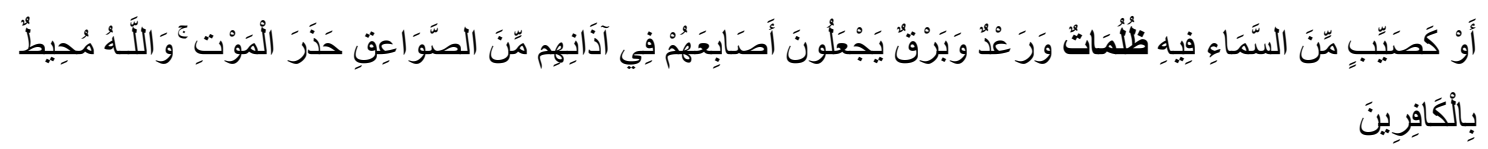

(Al-Baqarah:19)

Or like a rainstorm in the sky, bringing darkness, thunder, and lightning. They thrust their fingers in their ears to keep out the stunning thunderclap for fear of death. But Allah ever encompasses the disbelievers.

In this verse, darkness meaning the doubts, disbelief and hypocrisy. Allah mentioned that darkness only for Jews, Christiana, and Idolators who dislike Allah's messenger. However, Allah explained implicitly so that believers understanding the meaning in it and darkness showed euphemism realized implicitly. Allah realized euphemistic expression to avoid ambiguous meaning in understanding content. Another example of Surah AlBaqarah: 223 

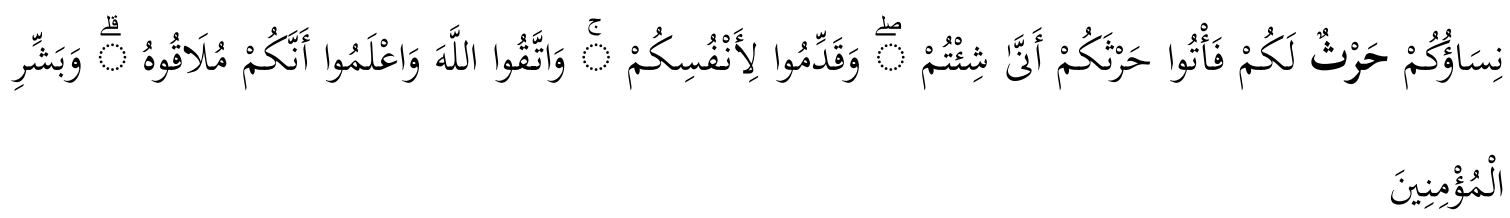

Your wives are a tilth for you, so go to your tilth, when or how you will, and send (good deeds, or ask Allah to bestow upon you pious of $f$ spring) for your own selves beforehand. And fear Allah, and know that you are to meet Him (in the Hereafter), and give good tidings to the believers (O Muhammad).

In the word tilth ( حَرٌُُّْ ) have meaning the place of pregnancy. It showed a euphemistic expression used to soften a vulgar or taboos. If Allah mentioned directly place of pregnancy in this verse, so many Muslim misinterpretation and have negative meaning. In addition, they think that Al-Qur'an have not power because the power of Al-Qur'an is

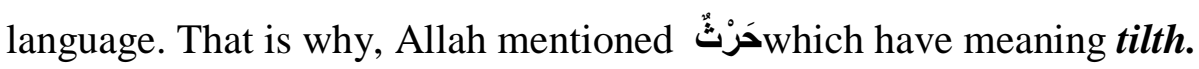

\section{b. Explicit}

Explicit refers to something that is specific, clear, or detailed. In the holy Qur'an, Allah has explained covenant, punishment, and reward clearly and briefly to believers and disbelievers who want to follow Him. There were some verses of euphemism realized explicitly. The data can be seen below:

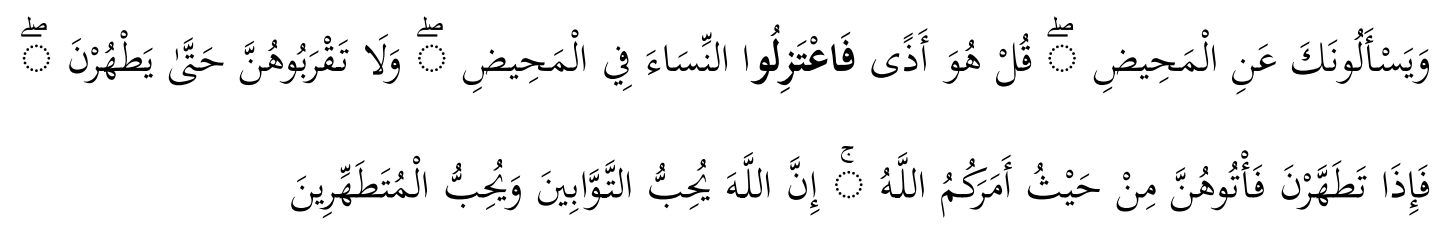

(Al-Baqarah: 222)

They ask you concerning menstruation. Say: "That is an Adha, therefore, keep away from women during menses and go not in unto them till they are purified. "And when they have purified themselves, then go in unto them as Allah has ordained for you. Truly, Allah loves those who turn unto Him in repentance and loves those who purify themselves.

In this verse, Allah explained clearly and briefly command to avoid their menstruating women, they would not eat, or even mingle with them in the house. The way of Allah mentioned explicitly about laws and attitudes in intercourse to their wife. Allah mentioned explicitly as proof in Al-Qur'an when Muslim deliver to another Muslim about laws of Allah. As Indonesia have norm and laws in UUD 1945. In this verse explained that Allah's Messenger said: Do everything you wish, except having sexual intercourse. Therefore, keep away from women during menses. It means to avoid the sexual organ. This is why most of 
the scholars said that it is allowed to fondle the wife, except for havingsexual intercourse (when she is having her menses).

Another example of surah Al-Baqarah: 255

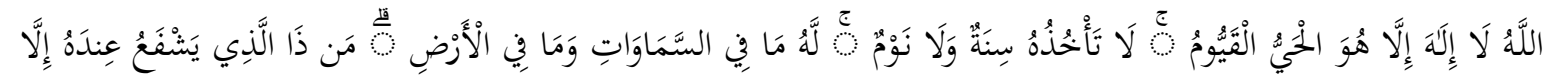

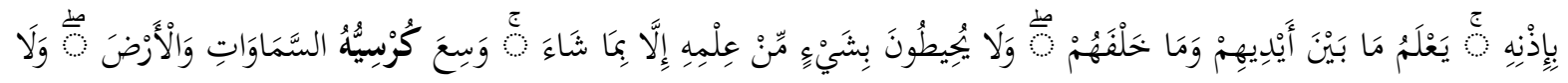

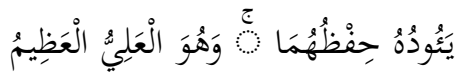

Allah! None has the right to be worshipped but He, the Ever Living, the One Who sustains and protects all that exists. Neither slumber nor sleep overtakes Him. To Him belongs whatever is in the heavens and whatever is on the earth. Who is he that can intercede with Him except with His permission He knows what happens to them (His creatures) in this world, and what will happen to them in the Hereafter. And they will never compass anything of His Knowledge except that which He wills. His Kursi extends over the heavens and the earth, and He feels no fa igue in guarding and preserving them. And He is the Most High, the Most Great

In this verse, His Kursi showed is the footstool, and no one is able to give due consideration to Allah's Throne. His Kursi showed that Allah is Wujud even though we cannot see Him. Allah created seven heavens, seven earths, human, plant, animal, and Allah is Rabbil 'alamin. Allah is the one, the merciful, and the gracious. Allah showed His Kursi is real in our life and clearly mentioned in Holy Al-Qur'an. This is the way of Allah showed His Kursi for knower and faithful.

c. Direct

Direct refers to aim something in a particular direction or at a particular person. There were some verses of euphemism realized directly. The data can be seen below:

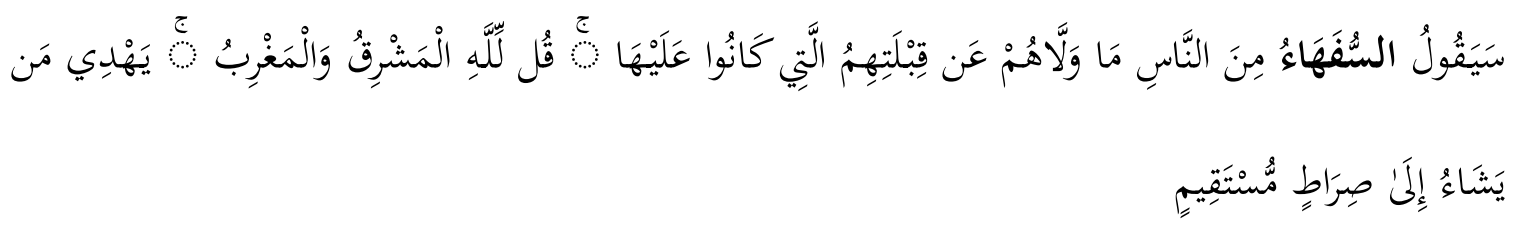

The fools (idolators, hypocrites, and Jews) among the people will say: "What has turned them (Muslims) from their Qiblah prayer direction (towards Jerusalem) to which they used to face in prayer. "Say (O Muhammad): "To Allah belong both, east and the west. He guides whom He wills to the straight way 
In this verse showed that السُقََهَاهُه only to the fools, namely people of Jews, Christians, Idolators, and hypocrites. They dislike when Allah's Messenger migrated to Al- Madinah, Allah commanded him to face Bayt Al-Maqdis (Jerusalem). The Jews were delighted then. Allah's Messenger faced Jerusalem for over ten months. However, he liked (to offer prayer in the direction of) Prophet Ibrahim's Qiblah (the Ka'bah in Makkah) and used to supplicate to Allah and kept looking up to the sky. Allah then revealed (turn your faces (in prayer) in that direction) meaning its direction. The Jews did not like this change and said: What made them change the Qiblah that they used to face (meaning Jerusalem). Allah revealed: (Say $(O$ Muhammad): To Allah belong both, east and the west. He guides whom He wills to the straightway.

Another example of Al-Baqarah: 83

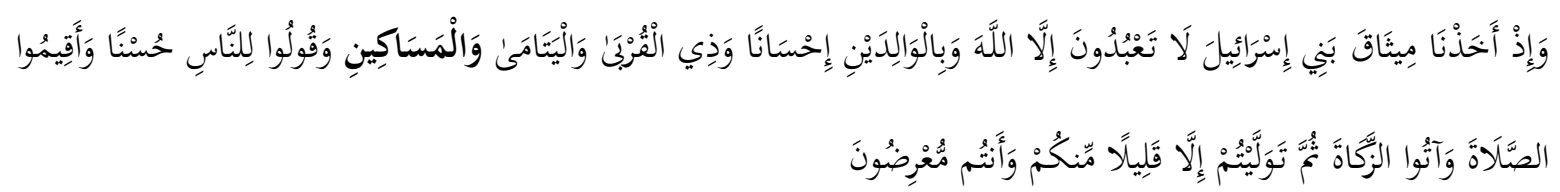

And (remember) when We took a covenant from the Children of Israel, (saying): Worship none but Allah (alone) and be dutiful and good to parents, and to kindred, and to orphans and (the poor), and speak good to people and perform As-Salah and give Zakah. Then you slid back, except a few of you, while you are backsliders.

In this verse, poordirectlyshowed for disable people. In addition,Allah directly commanded us to good to parents, and to kindred, and to orphans and (the poor), and speak good to people and perform As-Salah and give Zakah. Then you slid back, except a few of you, while you are backsliders. Allah commands the servants to say good words to people, af ter He commanded them to be kind to them, thereby mentioning two categories of manners: good speech and good actions. From the explanation above that Allah is Arrahman and Arrahim.

\section{d. Indirect}

Indirect refers to not immediate point person or thing to an action is done. There were some verses of euphemism realized directly. The data can be seen below:

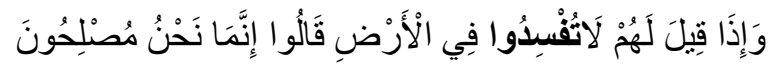
And when it is said to them: Make not mischief on the earth, they say: We are only peacemakers. 
In this verse, Allah mentioned indirectly person who made mischief in the earth. Ibn Jarir said, "The hypocrites commit mischief on earth by disobeying their Lord on it and continuing in the prohibited acts. They also abandon what Allah made obligatory and doubt His religion, even though He does not accept a deed from anyone except with faith in His religion and certainty of its truth. The hypocrites also lie to the believers by saying contrary to the doubt and hesitation their hearts harbor. They give as much aid as they can, against Allah's loyal friends, and support those who deny Allah, His Books and His Messengers. This is how the hypocrites commit mischief on earth, while thinking that they are doing righteous work on earth. " The statement by Ibn Jarir is true, taking the disbelievers as friends is one of the categories of mischief on the earth.

Another example of surah Al-Baqarah: 256

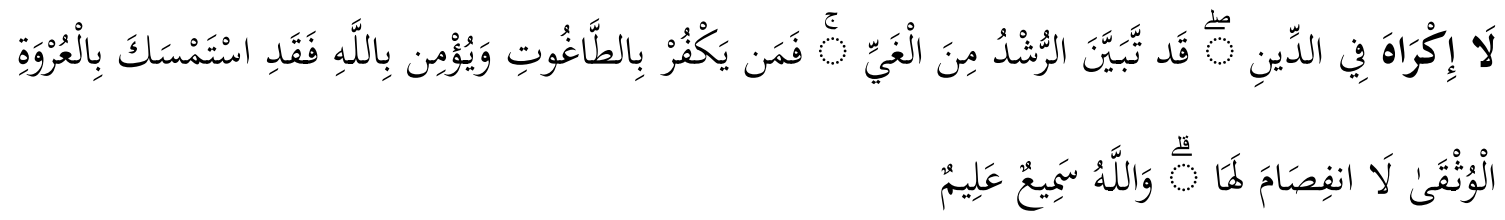

There is no compulsion in religion. Verily, the right path has become distinct from the wrong path. Whoever disbelieves in Taghut and believes in Allah, then he has grasped the most trustworthy handhold that will never break. And Allah is All-Hearer, All-Knower.

In this verse showed that Allah no compulsionin religion. It means that Allah not force someone to enter Islam. Everyone has freedom in choosing religion (Ad-din). However, Allah has explained that whoever want to follow Him, soAllah will give Gardens under which rivers flow (Paradise). Every time they will be provided with a fruit therefrom, and they will be given things in resemblance (i.e. in the same form but different in taste) and they shall have therein Azwaj un Mutahharatun (purified mates or wives), and they will abide therein forever. It is Allah's covenant in Holy Qur'an.

\section{CONCLUSIONS}

From the data analysis, it is found that the ways of euphemism realized in surah AlBaqarah, namely direct, indirect, implicit, and explicit.The dominant of ways realized euphemism in surah Al-Baqarah was direct. It means that the most of euphemism to describe truth from Allah is real and Allah delivered messangers directly about the laws of Allah so that they can know the truth. 
It is a suggestion that further studies should be conducted study to find out more the ways euphemism realized in same context by providing more data to enrich the analysis of euphemism in the holy Qur'an.

\section{REFERENCES}

Allan, K., \& Burridge, K. (1991). Euphemism and dysphemism: Language used as shield and weapon. New York: OxfordUniversity Press

Alhamad, M. Q \& Salman, A. M. (2013). The Translatability of Euphemism in the Holy Qur'an. European Scientific Journal. Jordan: German Jordanian University. Vol.9, No.2 ISSN: 1857 - 7881

Bogdan, R. and Biklen, S.K. (1992). Qualitative Research for Education: An Introduction to Theory and Methods. Boston: Allyn and Bacon

Berg, B. L. (2007). Qualitative Research Methods for the Social Sciences. 6th Edition. San Francisco: Pearson Education, Inc.,

Miles, M. B, Huberman, A.M\& Saldana, J. (2014). Qualitative Data Analysis. USA: Sage

Rodulovic, Millica. (2012). Expressing Values in Positive and Negative Euphemisms. International Journal Linguistic and Literature. Serbia: University of Niš Vol. 10, No 1.

Wardhaugh, R. (1986). An Introduction to Sociolinguistics. The UK: Blackwell.

Warren, B. (1992). What euphemisms tell us about the interpretation of words. Studia Linguistica. EBook. 